\title{
Bone marrow transplantation in sickle cell anaemia
}

Ch Vermylen, G Cornu, M Philippe, J Ninane, A Borja, D Latinne, A Ferrant, J L Michaux, G Sokal

Abstract

Sickle cell anaemia is still responsible for severe crippling and death in young patients living in developing countries. Apart from prophylaxis and treatment of infections, no active treatment can be safely proposed in such areas of the world. Therefore a bone marrow transplantation was performed in 12 patients staying in Belgium and planning to return to Africa.

Twelve patients, aged between 11 months and 23 years (median 4 years), underwent a HLA identical bone marrow transplantation. The conditioning regimen included oral busulphan for four consecutive days $(4 \mathrm{mg} / \mathrm{kg}$ ) followed by four days of intravenous cyclophosphamide $(50 \mathrm{mg} / \mathrm{kg})$. In 10 patients the engraftment was rapid and sustained. $A$ further patient suffered transient red cell hypoplasia and another underwent a second bone marrow transplantation from the same donor at day 62 because of graft rejection. All patients are alive and well with a follow up ranging from 9-51 months (median 27 months). In all cases a complete cessation of vaso-occlusive episodes and haemolysis was observed as was a change in the haemoglobin pattern in accordance with the donor's electrophoretic pattern.

Sickle cell anaemia remains a disorder with a high morbidity and mortality rate. The mortality rate in Zaire is not known but is likely to be similar or even worse than that in Jamaica ${ }^{1}$ where 10 to $20 \%$ of children with sickle cell anaemia die during the first decade of life from severe infections, acute splenic sequestration, or cerebrovascular accidents. In the USA a prospective study gives a mortality rate of $3.3 \%$ before the age of 20 years. ${ }^{2}$ Apart from prophylaxis of infections with oral penicillin and vaccination against Streptococcus pneumoniae, the treatment is mainly symptomatic: analgesics and transfusions. New therapeutic approaches include stimulation of fetal haemoglobin production, ${ }^{3}$ but also manipulation of the oxygen saturation curve of haemoglobin $S,{ }^{4}$ reduction of the mean corpuscular haemoglobin concentration by increase of the water content of sickle cells, ${ }^{56}$ and modification of the membrane adhesive properties of the sickle cell. ${ }^{7}$ Further studies and controlled trials are necessary to evaluate the benefits and side effects of these treatments. Another approach, which unfortunately cannot be offered to all patients but has the advantage of reversing the clinical and haematological manifestations of the disease, is bone marrow transplantation. Preliminary results were reported in 1988 and encouraged us to pursue this approach. ${ }^{8}$

\section{Methods}

This study was approved by the ethical committee of our hospital. All risks of the treatment procedures were explained to the patients, donors, and relatives and informed consent was obtained.

\section{PATIENT SELECTION}

Twelve black patients with sickle cell anaemia underwent a HLA identical bone marrow transplantation. Eleven were from Zaire and one from Cameroon. Three were in Belgium for three to four years because their parents were studying. One patient aged 23 years was a student at our university. The eight other patients came to Belgium for the procedure and all 12 planned to return as soon as possible to their native country. Patients were selected because of the severity of the disease, their young age (11 months-23 years, median 4 years), a good general condition, the absence of HIV infection, and the presence of a healthy HLA identical donor in the family. The severity of the disease was difficult to evaluate. All patients had a median of four (range $1-6$ ) vasoocclusive episodes per year and occasionally required blood transfusions (table). The youngest patient (patient 2) was 11 months at the time of transplantation and had suffered only one vaso-occlusive episode but had already been transfused twice. The oldest patient (patient 10) was 23 years old at the time of transplantation and was ready to accept any treatment, even potentially dangerous, instead of suffering four to five vaso-occlusive episodes per year. She had an arthrodesis of the right hip at the age of 14, a left hip prosthesis at the age of 16 , and severe limitation of movement of the left shoulder, all problems being sequelae of infection or aseptic necrosis. The other patients had no chronic organ damage at the time of bone marrow transplantation. Details of the patients are shown in the table.

Haemoglobin components were separated and quantified by fast protein liquid chromatography. ${ }^{9}$ The haemolysates were chromatographed through a strong cation exchange column (Mono $S^{R}$ HR 5/5) for determination of haemoglobins $A, S$, and $F$ and detection of haemoglobin $A_{2}$ was done using an anion exchange column (Mono $\mathrm{q}^{\mathrm{R}} \mathrm{HR}$ 5/5). In some patients the $\beta: \alpha$ chain ratio was measured in order to look for $\alpha$ thalassaemia association. ${ }^{10}$ 
Details of patients who had bone marrow transplantation

\begin{tabular}{|c|c|c|c|c|c|c|c|c|c|c|}
\hline \multirow{2}{*}{$\begin{array}{l}\text { Patient } \\
\text { No }\end{array}$} & \multirow[t]{2}{*}{ Sex } & \multirow{2}{*}{$\begin{array}{l}\text { Age } \\
\text { (years) }\end{array}$} & \multirow{2}{*}{$\begin{array}{l}\text { Mean No of } \\
\text { vaso-occlusive } \\
\text { episodes/year }\end{array}$} & \multirow{2}{*}{$\begin{array}{l}\text { Mean No of } \\
\text { transfusions } \\
\text { lyear }\end{array}$} & \multicolumn{3}{|c|}{ Haemoglobin pattern } & \multirow{2}{*}{$\begin{array}{l}\text { Haemoglobin } \\
(\mathrm{g} / \mathrm{l})\end{array}$} & \multirow{2}{*}{$\begin{array}{l}\text { Mean } \\
\text { corpuscular } \\
\text { volume } \\
\text { (fl) }\end{array}$} & \multirow{2}{*}{$\begin{array}{l}\text { Mean } \\
\text { corpuscular } \\
\text { haemoglobin } \\
(\mathrm{g} / \mathrm{l})\end{array}$} \\
\hline & & & & & $\begin{array}{l}S \\
(\%)\end{array}$ & $\begin{array}{l}F \\
(\%)\end{array}$ & $\begin{array}{l}A_{2} \\
(\%)\end{array}$ & & & \\
\hline $\begin{array}{r}1 \\
2 \\
3 \\
4 \\
5 \\
6 \\
7 \\
8 \\
9 \\
10 \\
11 \\
12\end{array}$ & $\begin{array}{l}\mathbf{F} \\
\mathbf{M} \\
\mathbf{F} \\
\mathbf{F} \\
\mathbf{F} \\
\mathbf{M} \\
\mathbf{F} \\
\mathbf{M} \\
\mathbf{F} \\
\mathbf{F} \\
\mathbf{F} \\
\mathbf{F}\end{array}$ & $\begin{array}{c}3 \\
0 \cdot 9 \\
4 \\
9 \\
3 \\
7 \\
1 \\
13 \\
7 \\
23 \\
1 \cdot 7 \\
12\end{array}$ & $\begin{array}{l}4 \\
1 \\
4 \\
4 \\
4 \\
4 \\
6 \\
5 \\
4 \\
4 \\
4 \\
5 \\
2 \\
3\end{array}$ & $\begin{array}{l}3 \\
2 \\
3 \\
0-1 \\
0-1 \\
0-1 \\
0-1 \\
0-1 \\
0-1 \\
0-1 \\
2 \\
2\end{array}$ & $\begin{array}{l}79 \cdot 1 \\
77 \cdot 3 \\
78 \cdot 4 \\
90 \cdot 2 \\
89 \cdot 5 \\
88 \cdot 2 \\
90 \cdot 2 \\
93 \cdot 4 \\
90 \cdot 7 \\
94 \cdot 5 \\
74 \cdot 6 \\
92 \cdot 4\end{array}$ & $\begin{array}{r}20.3 \\
22 \cdot 0 \\
20 \cdot 0 \\
9.0 \\
9 \cdot 4 \\
9 \cdot 3 \\
7 \cdot 5 \\
3 \cdot 1 \\
6 \cdot 1 \\
1.4 \\
22 \cdot 5 \\
3.9\end{array}$ & $\begin{array}{l}0.6 \\
0.7 \\
1.6 \\
0.8 \\
1.1 \\
2.5 \\
2.3 \\
3.5 \\
3 \cdot 2 \\
4 \cdot 1 \\
2.9 \dagger \\
3.7\end{array}$ & $\begin{array}{l}76 \\
64 \\
76 \\
85 \\
76 \\
73 \\
76 \\
74 \\
96 \\
84 \\
71 \\
76\end{array}$ & $\begin{array}{l}79 \cdot 8 \\
72 \cdot 6 \\
83 \cdot 7 \\
86 \cdot 9 \\
76 \cdot 0 \\
93 \cdot 0 \\
77 \cdot 5 \\
71 \cdot 0 \\
84 \cdot 0 \\
77 \cdot 0 \\
79 \cdot 0 \\
72 \cdot 0\end{array}$ & $\begin{array}{l}324 \\
332 \\
321 \\
366 \\
323 \\
321 \\
337 \\
373 \\
330 \\
307 \\
337 \\
354\end{array}$ \\
\hline
\end{tabular}

${ }^{*} \beta: \alpha=1 \cdot 6,+\beta: \alpha=1 \cdot 2$.

DONORS

Donors were identical for HLA-A, B, C, and D/ DR locus as determined by serological typing and mixed lymphocyte culture. When possible, genotypical analysis of the entire family was performed. Donors were siblings in 11 cases and the father in one (patient 4), their age ranged from 1-32 years. They either had a normal haemoglobin electrophoresis pattern (AA, $n=4$ ) or were carriers of the sickle cell trait (AS, $n=8$ ). When possible the haemoglobin electrophoresis of the entire family was also studied. In all cases it was shown that the parents were carriers of the sickle cell trait.

\section{SUPPORTIVE CARE}

Prophylaxis of infections included oral colistin, vancomycin, and amphotericin $B$ during the inpatient period, oral acyclovir $(10-20 \mathrm{mg} / \mathrm{kg}$ ) for one year, and intravenous hyperimmune plasma containing cytomegalovirus antibodies twice a week for three months and once a week for two months. In patients who received short term steroid treatment for acute graftversus-host disease (GVHD), co-trimoxazole ( $3 \mathrm{mg}$ trimethoprim $/ \mathrm{kg}$ ) was given during one year for Pneumocystis carinii prophylaxis.

\section{CONDITIONING REGIMEN AND GVHD}

PROPHYLAXIS

Busulphan $(4 \mathrm{mg} / \mathrm{kg} /$ day) was given orally for four consecutive days followed by four days of intravenous cyclophosphamide $(50 \mathrm{mg} / \mathrm{kg} / \mathrm{day})$. In patients above 12 years of age preparation included also a thoracoabdominal irradiation $(750$ cGy over six hours) with an $18 \mathrm{MeV}$ linear accelerator, the lungs being shielded.

Prevention of GVHD included intravenous cyclosporin $(5 \mathrm{mg} / \mathrm{kg} /$ day $)$ for 14 to 21 days and then oral cyclosporin $(12 \mathrm{mg} / \mathrm{kg} / \mathrm{day})$ for six to 12 months, serum concentrations were kept between 100 and $150 \mathrm{ng} / \mathrm{ml}$ (measured by radioimmunoassay). In patients older than 12 years intravenous methotrexate $\left(10 \mathrm{mg} / \mathrm{m}^{2}\right)$ was given on days $1,3,6$, and 11 after transplantation.

Patients who developed acute GVHD received methylprednisolone ( $2 \mathrm{mg} / \mathrm{kg} /$ day) until a complete response was obtained, and the dosage was then tapered over several days.

In patient 4 , a second bone marrow trans- plantation was performed on day 62 because of graft rejection. The conditioning regimen was as described by Storb et al. ${ }^{11}$ Chemotherapy included four days of intravenous cyclophosphamide $(50 \mathrm{mg} / \mathrm{kg} /$ day), and a 10 hour infusion of antithymocyte globulin (Upjohn, $30 \mathrm{mg} / \mathrm{kg} /$ day) 12 hours after the first, second, and third doses of cyclophosphamide. The day before transplantation the patient underwent thoracoabdominal irradiation (750 cGy over six hours) with an $18 \mathrm{MeV}$ linear accelerator (lungs being shielded). Bone marrow was infused 36 hours after the last dose of cyclophosphamide. GVHD prophylaxis included cyclosporin and methotrexate as described above.

\section{Results}

\section{SHORT TERM FOLLOW UP}

In 10 patients the bone marrow engrafted without major complications. Patient 4 rejected the graft after the engraftment had been confirmed; a second transplant was performed on day 62 with an uneventful recovery. Patient 8 had prompt white cell and platelet recovery but the red cell series engraftment remained poor until five months after transplantation. Patients $1,4,6$, and 8 had grade I-II acute GVHD of short duration. Bone marrow transplantation related toxicity was analysed according to the World Health Organisation (WHO) recommendations. ${ }^{12}$ It included oral mucositis (WHO score 3) and diarrhoea (WHO score 1) in 11 patients. In patient 10 mucositis was severe (WHO score 4) and renal function impaired (WHO score 2) until day 21. One patient developed a Klebsiella pneumoniae bacteraemia that responded promptly to an aminoglycoside$\beta$ lactam combination. The same antibiotic regimen was successfully used in all the other patients who developed a fever of unknown origin while neutropenic. The time necessary to recover a neutrophil count above $1 \times 10^{9} / 1$ and a platelet count above $150 \times 10^{9} / 1$ was $14-30$ days (median 19 days) and 17-110 days (median 39 days) respectively.

\section{LONG TERM FOLLOW UP}

The follow up ranges from 9-51 months (median 27 months). All 12 patients are in good general condition and none has had a vaso-occlusive 
episode since transplantation. Patient 8 required blood transfusions during the first five months but is now doing well with a follow up of 22 months. In 11 patients the chromatographic pattern of the haemoglobin became similar to that of the donor (AA, $n=3 ; A S, n=8$ ). Although the donor was AA in patient 3 a small amount of haemoglobin $S$ is still present (3\%) 36 months after transplantation, suggesting mixed chimerism. In the six patients having a donor of the opposite sex, cytogenetic studies confirmed the presence of bone marrow cells from the donor. Twelve months after bone marrow transplantation patient 1 developed autoimmune thrombocytopenia as shown by an increase in the number of megakaryocytes on bone marrow examination and by a fourfold increase in antiplatelet antibodies. Thrombocytopenia was first thought to be a sign of chronic GVHD, although there was no other symptom, and cyclosporin was restarted without success. Intravenous gammaglobulins were given without response. An increase in the platelet count was transiently noticed after steroids and azathioprine. Isotopic studies performed 18 months after transplantation showed increased splenic destruction of platelets and a platelet half life of 2.5 days (normal $4 \pm 0.5$ days). Splenectomy was performed 24 months after transplantation, but the response was only transient and the treatment with steroids was resumed in addition to azathioprine first, cyclophosphamide afterwards, and ascorbic acid. Finally, 40 months after transplantation and independently of all previous treatments, the platelet count became normal and the medications could be progressively stopped.

Among the 12 patients, seven went back to their native country and continue to do well.

\section{Discussion}

The first reported bone marrow transplant performed in a child with sickle cell anaemia was for acute myeloblastic leukaemia. ${ }^{13}$ Conversion of sickle cell anaemia into sickle cell trait suggested that bone marrow transplantation might be another possible treatment. To decide whether transplantation should or should not be offered to patients with sickle cell anaemia morbidity and mortality have to be compared between transplanted patients and patients receiving another treatment.

Our series is the first one to report on 12 young patients probably cured by bone marrow transplantation. One patient rejected the graft but was successfully regrafted from the same donor. Mixed lymphocyte culture was negative, there was no infection, no blood products from the donor had been transfused, and cytotoxic antibodies were absent. A possible reason for rejection is that, although recipient and donor were phenotypically identical, they were not genotypically identical, the donor being the father. Another patient required blood transfusions during the first five months because of prolonged erythroblastopenia. This patient's blood group was $\mathrm{O} R \mathrm{Rh}$ positive and the donor's was A Rh positive. Delayed red cell - series engraftment can occur with $\mathrm{ABO}$ incompatible bone marrow transplantation. ${ }^{14}$ Full engraftment is usual several months after tranplantation as was the case in our patient. In our 12 patients acute phase toxicity was acceptable and reversible in all of them. As far as long term toxicity is concerned, one patient developed immune thrombocytopenia one year after transplantation but complete remission was observed two years later. Risks related to the procedure can probably best be compared with those encountered in thalassaemic patients, the conditioning regimen being similar. In thalassaemic patients the incidence of chronic GVHD is $10 \% .{ }^{15}$ Although our series is small, chronic GVHD and rejection might be less often encountered because patients with sickle cell anaemia did not have complications of transfusion treatment. They had no hepatomegaly and concentrations of ferritin were only slightly raised. The young age of the patients is another factor for a good prognosis as far as chronic GVHD is concerned. ${ }^{16}$ Cytomegalovirus related complications were not seen.

The follow up is too short to evaluate the influence of bone marrow transplantation on growth, fertility, and secondary tumours. Growth and fertility will be difficult to evaluate because most children with sickle cell anaemia experience delayed puberty and are almost invariably thin. Concerning fertility, men with sickle cell anaemia have low sperm counts and women have normal fertility but with a high incidence of miscarriages and stillbirths. ${ }^{17}$. Toxicity of the conditioning regimen (busulphan and cyclophosphamide) is currently being evaluated in patients with acute non-lymphocyte leukaemia and chronic myeloid leukaemia. ${ }^{16}$

On the other hand, with conventional treatments morbidity and mortality rates in sickle cell anaemia remain high with at least 10 to $20 \%$ of children dying during the first decade of life. ${ }^{1}$ The majority of patients cannot afford long term antibiotic treatment for prophylaxis of infections, and blood transfusions should be avoided whenever possible in countries with a high incidence of HIV infection. ${ }^{18}$ Modern therapeutic approaches are based upon the knowledge that fetal haemoglobin interferes with sickling by reducing the tendency for polymerisation. ${ }^{19}$ Therefore, attempts have been made to stimulate the synthesis of fetal haemoglobin by azacytidine and hydroxyurea. Hydroxyurea seems more promising but patients have to be monitored very carefully because effectiveness is achieved at concentrations likely to cause bone marrow depression. ${ }^{3}$ Hopes were raised that erythropoietin might have an additive effect while decreasing toxicity of hydroxyurea, ${ }^{20}$ but a recent report showed that erythropoietin was of no benefit. ${ }^{21}$ Other studies are in progress with agents causing a better oxygenation of the red cell, ${ }^{14}$ reducing the mean corpuscular haemoglobin concentration, ${ }^{56}$ or modifying membrane properties of sickle cells. ${ }^{7}$ These approaches need however to be further studied and controlled trials are necessary.

At the present time bone marrow transplantation is the only treatment offering the possibility of eliminating the sickling phenomenon and its consequences. Benefits and risks related to the procedure must be balanced. Patients should be 
old enough to have an understanding of the severity of their disease but young enough to be in good general condition, free of HIV infection, without chronic organ damage, without haemochromatosis, and at a low risk of developing chronic GVHD. Furthermore, bone marrow transplantation should essentially be proposed to patients wishing to return to their native countries where patients with sickle cell anaemia are at risk of malnutrition and infections.

We thank M P Berckmans for typing the manuscript

1 Rogers DW, Clarke JM, Cupidore L, et al. Early deaths in Jamaican children with sickle cell diease. $B M \mathcal{F} 1978 ; 278$ : J515-6.

2 Leikin SL, Gallagher D, Kinnely TR, Sloane D, Klug P, Rida W, and the cooperative study of sickle cell disease. Mortality in children and adolescents with sickle cell disease. Pediatrics 1989;84:500-8.

3 Rodgers GP, Dover GJ, Noguchi CT, Schechter AN, Nienhuis AW. Hematologic responses of patients with sickle cell disease to treatment with hydroxyurea. $N$ Engl f Med 1990;322:1037-45.

4 Keidan AJ, Sowter MC, Johnson CS, Marwah SS, Stuart J. Pharmacological modification of oxygen affinity improves deformability of deoxygenated sickle erythrocytes: a possible therapeutic approach to sickle cell disease. Clin Sci 1989; 76:357-62.

5 Nash GB, Boghossian S, Parmar J, Dormandy JA, Bevan D. Alteration of the mechanical properties of sickle cells by repetitive deoxygenation: role of calcium and effects of repetitive deoxygenation: role of calcium and
calcium blocker. $B r 7$ Haematol 1989;72:260-4.

6 Ney PA, Christopher MM, Hebbel RP. Synergistic effects of oxidation and deformation on erythrocyte monovalent cation oxidation and deformation on

7 Gini EK, Sonnet J. Use of piracetam improves sickle cell deformability in vitro and in vivo. $\mathcal{F}$ Clin Pathol 1987;40: 99-102.
8 Vermylen C, Fernandez Robles E, Ninane J, Cornu G. Bone marrow transplantation in five children with sickle cell marrow transplantation in five

9 Kramlova M, Pristoupil TI, Fricova V, Kraml J, Berglund R Kantardiiev N. Fast protein liquid chromatography of pyridoxalated and glutaraldehyde treated human haemoglopyridoxalated and glutaraldehyde treated human
bin. Fournal of Chromatography 1981;249:403-4.

10 Rahbar S, Asmerom Y. Rapid HPLC techniques for globin chain synthesis studies. Hemoglobin 1989;13:475-87.

11 Storb R, Weiden PL, Sullivan KM, et al. Second marrow transplantation in patients with aplastic anemia rejecting the first graft: use of a conditioning regimen including cyclophosphamide and antithymocyte globulin. Blood 1987;70: 116-21.

12 World Health Organisation. WHO handbook for reporting results of cancer treatment. Geneva: WHO, 1979. (WHO offset publication No 48 .)

13 Johnson FL, Look AT, Gockerman J, Ruggiero MR, DallaPozza L, Billings FT. Bone-marrow transplantation in a patient with sickle-cell anemia. $N$ Engl $\mathcal{F}$ Med 1984;311: patient

14 Gmür JP, Burger J, Schaffner A, et al. Pure red cell aplasia of long duration complicating major ABO-incompatible bone long duration complicating major ABO-incom
marrow transplantation. Blood 1990;75:290-5.

15 Lucarelli G, Galinberti M, Polchi $P$, et al. Bone marrow transplantation in patients with thalassemia. N Englf Med 1990; 322:417-21.

16 Geller RB, Saral R, Piantadosi S, et al. Allogeneic bone marrow transplantation after high-dose busulfan and cyclophosphamide in patients with acute nonlymphocytic leukemia. Blood 1989;73:2209-18.

17 Brozovic M, Davies S. Management of sickle cell disease. Postgrad Med f 1987;63:605-8.

18 Nzilambi N, De Cock KM, Forthal DN, et al. The prevalence of infection with human immunodeficiency virus over a 10-year period in rural Zaire. $N$ Engl f Med 1988;318: 276-9.

19 Schechter AN, Noguchi CT, Rodgers GP. Sickle cell anaemia. In: Stamatoyasnnopoulos G, Nienhuis AN, Leder P, Majerus PW, eds. The molecular basis of blood diseases. Philadelphia: W B Saunders, 1987:179-218.

20 Al-Khatti A, Veith RW, Papayannopoulos T, Fritsch EF Goldwasser E, Stamatoyannopoulos G. Stimulation of fetal hemoglobin synthesis by erythropoietin in baboons. $N$ Engl hemoglobin synthesis by

21 Goldberg MA, Bringnara C, Dover GJ, Schapira L, Charache C, Bunn HF. Treatment of sickle cell anemia with hydrox urea and erythropoietin. $N$ Engl $\mathcal{F}$ Med 1990;323:366-72. 